\title{
Stratigraphic subdivision of Tertiary sediments Of Well 1 using total organic carbon (TOC) and gamma ray (GR) log: Case study, the Niger Delta
}

\author{
Benson Akinbode Olisa and Ayomide Samson Ifanegan \\ The Federal University of Technology, Akure, Nigeria. \\ DOI: $10.31364 /$ SCIRJ/v9.i10.2021.P1021887 \\ http://dx.doi.org/10.31364/SCIRJ/v9.i10.2021.P1021887
}

\begin{abstract}
Traditional methods of stratigraphic subdivision are based on biostratigraphy and well log analyses. The Tertiary Niger Delta is divided into Paleogene and Neogene. When biostratigraphic and well log data are not available, the method of total organic carbon (TOC) and geophysical responses of organic matter might be used. TOC (wt\%) is related to gamma ray (API). TOC is first calculated from the GR $\log$. The calculated TOC, GR( TOC) is plotted against depth. Results show that TOC decreases with depth. Miocene section (Neogene) has the highest value of TOC and Eocene (Palaeogene) has the lowest. There is a discontinuity surface between Oligocene and Miocene at 4500ft. This coincides with marker shale Bolivina 27 about 27.1Ma. Between Eocene and Oligocene in Well 1, the discontinuity is at 7100ft. This coincides with marker shale Uvigerinella 8 at about 38Ma.
\end{abstract}

\section{INTRODUCTION}

Study of stratigraphic evolution is done using high resolution biostratigraphy, Rull (2002). Fossil remains preserved in sediments are used for stratigraphic analysis. These sediments, most especially shales, can be processed and examine under the microscope for taxonomic purposes.

Using laboratory method for chronostratigraphic subdivision has requirements that are difficult to meet. For example, samples are required for analysis. The samples have to be moved from the field to the laboratory. Geophysical method of well log analysis could be an alternative to the laboratory method, because results of analysis will represent in-situ- conditions.

Organic carbon is the remains of organisms preserved in sediments as kerogen, and after burial they undergo transformation due to pressure and temperature and are converted to hydrocarbons. The kerogens could be related to different age groups in the geological time scale.

The gamma ray log has responses to organic matter (kerogen) in sediments. If matrix and fluids effects could be removed, the gamma ray $\log$ have a direct relationship with radioactivity in the sediments, Meissner (1978), Jia et al. (2012).

In stratigraphic subdivision, the organic matter is assessed from the sediments by calculating total organic carbon (TOC) from gamma ray $\log$ and then related to stratigraphy. Results show that TOC calculated using the GR log are comparable and could be used in each case for stratigraphic interpretation.

\section{Geology of Niger Delta}

The Niger Delta, Figure 1, a passive continental margin is situated between longitude $3^{0}$ and $9^{0} \mathrm{~N}$ and latitude $4^{0}$ and $6^{\circ} \mathrm{N}$ (Amigun $e t$ al. (2013).

\section{Evolutionary history}

The Tertiary Niger Delta sediment is made of Paleogene (Palaeocene, Eocene and Oligocene) and Neogene (Miocene, Pliocene and Peistocene), Figure 1 and Table 1.

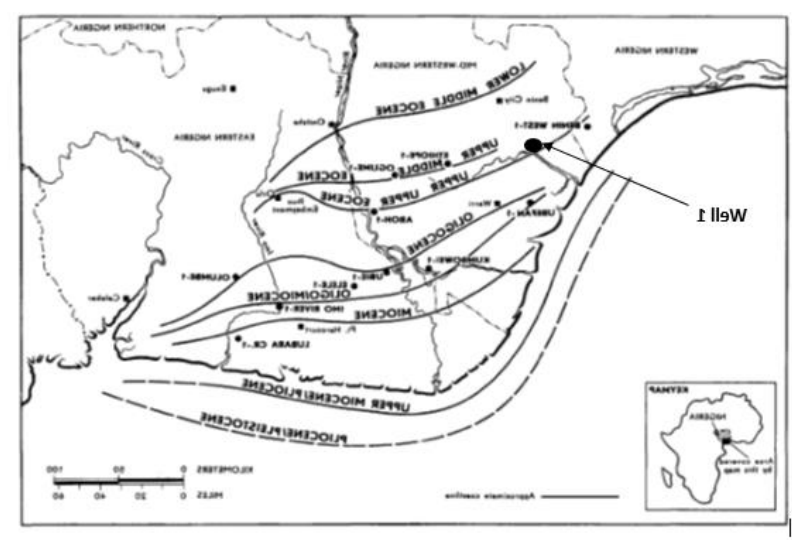

www.sciri.org

(C) 2021, Scientific Research Journal

http://dx.doi.org/10.31364/SCIRJ/v9.i10.2021.P1021887

This publication is licensed under Creative Commons Attribution CC BY. 
Figure 1: Paleogeographic regions of the Niger Delta (Short and Stauble 1967).

\section{Depositional history}

The Niger Delta sediments had been divided into 29 palynological zones and subzones, Table 1, each having an alphanumeric code (e.g., P630), Evamyl et al. (1971).

Table 1: Chronostratigraphic equivalence of the palynological zonations for the Niger Delta

\begin{tabular}{|c|c|c|c|c|c|c|c|}
\hline System & Period & Epoch & Age (Ma) & & \multicolumn{3}{|c|}{ Formations } \\
\hline \multirow{15}{*}{$\frac{\frac{\pi}{0}}{\frac{\pi}{2}}$} & \multirow{6}{*}{$\begin{array}{l}\stackrel{\mathbf{d}}{\mathbf{d}} \\
0 \\
0 \\
\mathbf{d} \\
\mathbf{Z}\end{array}$} & \multirow{6}{*}{ 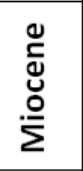 } & Messinian & P850 & \multirow{6}{*}{ 동 } & \multirow{8}{*}{ 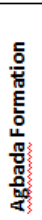 } & \multirow{15}{*}{ 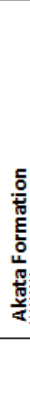 } \\
\hline & & & Tortonian & P820 & & & \\
\hline & & & Serravalian & P770 & & & \\
\hline & & & Langhian & P720 & & & \\
\hline & & & Burdigalian & P650 & & & \\
\hline & & & Aquitanian & P630 & & & \\
\hline & \multirow{9}{*}{ 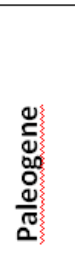 } & \multirow{2}{*}{ бо 品 } & Chattian & P580 & & & \\
\hline & & & Rupelian & P520 & & & \\
\hline & & \multirow{4}{*}{ 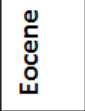 } & Priabonian & P480 & & & \\
\hline & & & Bartonian & P470 & & & \\
\hline & & & Lutetian & P420 & & & \\
\hline & & & Ypresian & P330 & & & \\
\hline & & \multirow{3}{*}{$\left.\frac{d}{d} \frac{d}{d}\right\}$} & Thanetian & P200 & & & \\
\hline & & & Selandian & & & & \\
\hline & & & Danian & & & & \\
\hline
\end{tabular}

Paleocene and Eocene (P200-P480)

During the Paleocene and earliest Eocene (P200) times, marine shales were deposited over much of the southern Nigerian sedimentary basin. Near the end of late Eocene (P480), a major transgression commenced which accelerated the expansion of the Niger Delta. This regressive phase has continued until the present, frequently interrupted by generally minor regressions.

\section{Oligocene and early Miocene (P520-P580)}

During this period the successive depocenters in the west considerably overlapped, reflecting in general a pronounced subsidence and a relatively slow advance of the delta front toward the wet and southwest. This pattern of overlapping depocenters resulted in a rather thick development of paralic sediments over the western part of the delta. By contrast, the successive depocenters in the east generally do not overlap, and they reflect a more rapid advance of the delta front.

Miocene to present (P630-P680)

Later in the early Miocene, the hitherto separated depocenters gradually merged, and the enlarged delta began to prograde along a wide front (P680). The more rapid subsidence, and corresponding slower rate of advance of the delta front, continued to characterize the western part of the delta.
Depocenters continued to develop during the later Miocene. A large depocenter of late Miocene age (P860) is present in the eastern offshore.

\section{Materials and method}

Wells- 1 (Figure 1 and 2), located in the northern depobelt was used for the analysis. The well is $9446 \mathrm{ft}$, deep. Total organic carbon (TOC) data and biostratigraphic data (Palynology and microfossil) from laboratory were available for Eocene section (Tables 2, 3 and 4) as well as GR log (Figure 2). A modified stratigraphic chart of the Niger Delta is also available, Table 1.

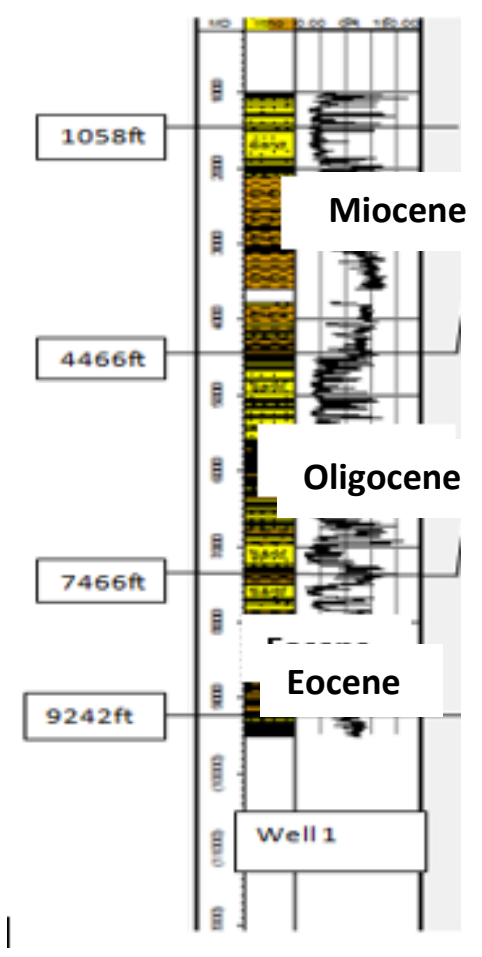

Figure 2: Lithology sequences of Well 1.

Table 2: Data (GR and Rock-Eval) for Well 1

\begin{tabular}{|c|c|c|}
\hline Well 1 & & \\
\hline Depth & GR (API) & Lab (TOC):wt\% \\
\hline 8930 & 72.91 & 3.1 \\
\hline 8960 & 71.26 & 3.6 \\
\hline 9000 & 81.99 & 3.7 \\
\hline 9030 & 74.26 & 4.2 \\
\hline 9050 & 72.26 & 3.7 \\
\hline 9090 & 86.46 & 3.4 \\
\hline 9110 & 78.01 & 4.2 \\
\hline 9150 & 78.51 & 3.3 \\
\hline 9180 & 80.76 & 2.9 \\
\hline 9200 & 69.22 & 3.7 \\
\hline
\end{tabular}




\begin{tabular}{|r|r|r|}
\hline 9240 & 75.56 & 2.9 \\
\hline 9260 & 62.22 & 4.3 \\
\hline 9300 & 51.27 & 3.4 \\
\hline 9330 & 71.96 & 3.3 \\
\hline
\end{tabular}

Table 3: Palynological zones of Well 1

\begin{tabular}{|c|c|c|c|c|}
\hline \multicolumn{5}{|c|}{ Well 1} \\
\hline $\begin{array}{c}\text { Top } \\
\text { Depth }\end{array}$ & $\begin{array}{l}\text { Botto } \\
\text { m } \\
\text { Depth }\end{array}$ & P-Zones & $\begin{array}{c}\text { Reliabilit } \\
\mathrm{y} \\
\text { Gradient }\end{array}$ & Remarks \\
\hline 0 & 2000 & Not Studied & & \\
\hline $\begin{array}{c}2230 . \\
0\end{array}$ & $\begin{array}{c}2690 . \\
0\end{array}$ & P670 & 1 & $\begin{array}{c}\mathrm{QB} \\
\text { Magnastriatites } \\
\text { howardii }(9)\end{array}$ \\
\hline $\begin{array}{c}2730 . \\
0\end{array}$ & $\begin{array}{c}2830 . \\
0\end{array}$ & $\begin{array}{c}\text { Indetermina } \\
\text { te }\end{array}$ & 3 & \\
\hline $\begin{array}{c}2870 . \\
0\end{array}$ & $\begin{array}{c}3078 . \\
0\end{array}$ & $\mathrm{P} 630 / ? \mathrm{P} 650$ & 2 & $\begin{array}{c}\text { Low } M . \\
\text { howardii (9); } \\
\text { high occurrence } \\
\text { Praedapollis } \\
\text { flexibilis (420) } \\
\end{array}$ \\
\hline $\begin{array}{c}3140 . \\
0\end{array}$ & $\begin{array}{c}4504 . \\
0\end{array}$ & P620 & 1 & $\begin{array}{c}\text { Top } \\
\text { Praedapollis } \\
\text { africanus (443) }\end{array}$ \\
\hline $\begin{array}{c}4570 . \\
0\end{array}$ & $\begin{array}{c}6340 . \\
0\end{array}$ & P520-P580 & 1 & $\begin{array}{c}\text { Cicatricosisporit } \\
\text { es dorogensis / } \\
\text { Gemmatriporite } \\
\text { s sp. (30 / 573); } \\
\text { Base } \\
\text { Racemonocolpit } \\
\text { es hians }(250)\end{array}$ \\
\hline $\begin{array}{c}6356 . \\
0\end{array}$ & $\begin{array}{c}6450 . \\
0 \\
\end{array}$ & $\begin{array}{c}\text { Indetermina } \\
\text { te }\end{array}$ & 3 & \\
\hline $\begin{array}{c}6670 . \\
0\end{array}$ & $\begin{array}{c}9276 . \\
0\end{array}$ & $\mathrm{P} 470-\mathrm{P} 480$ & 1 & $\begin{array}{c}\text { Top } \\
\text { Doualaidites } \\
\text { laevigatus ( 550) }\end{array}$ \\
\hline $\begin{array}{c}9306 . \\
0\end{array}$ & $\begin{array}{l}9470 . \\
0\end{array}$ & P450 & 1 & $\begin{array}{c}\text { Quantitative top } \\
\text { Monocolpites } \\
\text { marginatus } \\
(237) \\
\end{array}$ \\
\hline
\end{tabular}

Table 4: Well 1: Sequence Strat

\begin{tabular}{|c|c|l|}
\hline Depth & Ages & $\begin{array}{l}\text { Microfossils } \\
\text { (foraminifera)/marker } \\
\text { shales }\end{array}$ \\
\hline 4500 & 28.1 & Bolivina 27 \\
\hline 4800 & 29.3 & SB \\
\hline
\end{tabular}

\begin{tabular}{|c|c|c|}
\hline 5280 & 31.3 & Uvigerinella 5 \\
\hline 5450 & 32.4 & SB \\
\hline 5720 & 34.0 & Un-named \\
\hline 5890 & 35.4 & SB \\
\hline 5970 & 35.9 & Orogho Shale \\
\hline 6475 & 36.3 & SB \\
\hline 6800 & 36.8 & Un-named \\
\hline 6970 & 37.3 & SB \\
\hline 7487 & 38.0 & Uvigerinella 8 \\
\hline 7750 & 38.7 & SB \\
\hline 8600 & 39.4 & Un-named \\
\hline 8900 & 40.1 & SB \\
\hline 9440 & 41.0 & Umutu Shale \\
\hline
\end{tabular}

\section{Lithological analysis}

The GR log is used to divide the sediments into sand and shale. The Gamma ray log measures radioactivity in the sediments. Organic matter is more concentrated in shale than sand, Passey et al. (1990), therefore the gamma ray reading is more in shale than in sand. To identify shale from sand, $70 \%$ cut-off is used (Olisa and Oke 2014, Olisa and Okafor 2014).

\section{Total organic carbon (TOC) analysis}

The lithologic components of the Niger Delta are shales and sandstones (Short and Stauble, 1967). In the analysis the sand intervals were removed in order to concentrate on the shale sections. The Organic rich shales are present on top of Akata and base of Agbada sequence. The Organic richness is due to the presence of organic matter in the sediments and the organic matter present is disseminated in the rock. Organic rich rocks (shales) contain more than $1 \mathrm{wt} \%$ of TOC. Organic lean (sandstones) rocks have less than 1wt\% TOC, Meyer and Nederlof (1984). In the Niger Delta, TOC averaged 1.4 to $1.6 \%$ (Bustin, 1988), Organic rich rocks are made of three components; the matrix, the pore fluids (water, oil or gas) and organic matter, Passey (1990). The response of GR log in sediments is a result of all components combined. To determine the response of the geophysical log to organic matter, the influence of the matrix and the fluids has to be removed. This is done by application of necessary hypothesis to the logs and organic matter (Olisa et al. 2018a). Derived equation to calculate the TOC ia:

$Y=29.649 x-31.732$ 1

$$
\mathrm{y} \text { is GR, and } \mathrm{x} \text { is TOC. }
$$

Stratigraphic analysis

Palynological data, Table 3 was used to subdivide the sediments into their respective epochs in the well. The microfossils were 
used to identify the sequence boundaries. Equation 1 was used to calculate TOC from GR $\log$ at $1 \mathrm{ft}$ interval down the hole. Calculated TOC result for the well is plotted against the entire depth, Figure 3. Points of discontinuities are marked on the plot and then located on the well. Marker shales positions from biostratigraphic analysis were located on well. Points of discontinuities are determined. These points are correlated with biostratigraphic data for calibration.

\section{TOC (from gamma ray) versus depth}

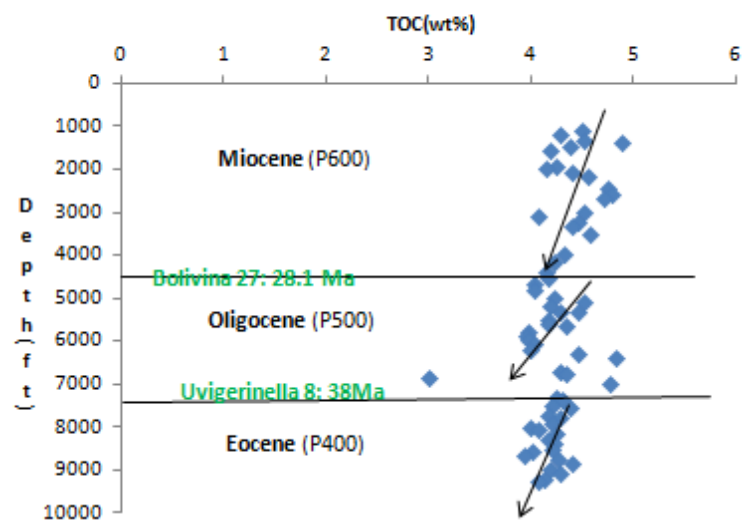

Figure 3: Plot of GR(TOC) versus Depth

\section{Results and discussions}

Table 5: Stratigraphy of well 1.

\begin{tabular}{|l|l|l|l|l|l|}
\hline \multicolumn{7}{|l|}{ Well 1 } \\
\hline $\begin{array}{l}\text { Depth } \\
\text { range(ft) }\end{array}$ & $\begin{array}{l}\text { Thickness } \\
\text { ft) }\end{array}$ & Stages & Epoch & $\begin{array}{l}\text { GR } \\
\text { av. }\end{array}$ & $\begin{array}{l}\text { GR } \\
\text { (TOC) }\end{array}$ \\
\hline $\begin{array}{l}1058- \\
4466\end{array}$ & 3408 & $\begin{array}{l}\text { P620- } \\
\text { P670 }\end{array}$ & Miocene & 87 & 3.98 \\
\hline $\begin{array}{l}4466- \\
7466\end{array}$ & 3000 & $\begin{array}{l}\text { P520- } \\
\text { P580 }\end{array}$ & Oligocene & 82 & 3.93 \\
\hline $\begin{array}{l}7466- \\
9232\end{array}$ & 1766 & $\begin{array}{l}\text { P480/ } \\
\text { P470 }\end{array}$ & Eocene & 79. & 4.26 \\
\hline
\end{tabular}

Table 5 shows variations of GR (TOC) with depth. There are discontinuities at $4500 \mathrm{ft}$ and $7500 \mathrm{ft}$ which represent OligoceceMiocene and Eocene-Oligocene boundaries respectively. Top of marker shales Bolivina 27 (28.1Ma) and Uvigerinella 8 (38Ma) are located at the respective depths.
The thickness of Miocene section is $3408 \mathrm{ft}$ with 34 shale sections. The calculated GR (TOC) range is $4.14-4.88 \mathrm{wt} \%$ ) (Average is $4.22 \mathrm{wt} \%)$ ). The TOC decreases with depth.

The Oligocene section has a thickness of $3000 \mathrm{ft}$ with 46 shale sections. The calculated GR (TOC) range is $3-4.51 \mathrm{wt} \%$ (average is $4.2 \mathrm{wt} \%$ ). The TOC decreases with depth.

The thickness of Eocene section is 1766ft. The calculated TOC (gamma ray) range is $3.94-4.37 \mathrm{wt} \%$ (average is $4.18 \mathrm{wt} \%$ ). The TOC increases with depth.

\section{Conclusion}

TOC derived from geophysical log was used for stratigraphic subdivision in the Niger Delta. There are two geological boundaries delineated in well 1 . The boundary between Eocene and Oligocene is $4465 \mathrm{ft}$. This corresponds to top of the marker shale Bolivina $27(28.1 \mathrm{Ma})$ at $4500 \mathrm{ft}$ from the laboratory (biostratigraphy). At well 2, the geological boundary is at $6647 \mathrm{ft}$. The geological boundary is at $4976 \mathrm{ft}$ in well 3 .

The TOC decreases with depth from Miocene to Eocene.

\section{References}

Amigun J. O., B. Olisa and O. O. Fadeyi, 2012, Petrophysical analysis of well $\operatorname{logs}$ for reservoir Evaluation: A case study of 'Laja' Oil Field, Niger Delta: Journal of Petroleum and Gas Exploration Research, Vol. 2(10) pp. 181-187.

Evamy b. D., J. Haremboure, P. Kamerling, W. A. Knaap, F. A. Molloy and P. H. Rowlands, 1971, Hydrocarbon Habitat of Niger Delta: AAPG Bulletin, v. 62, p. 1- 39.

Jia J., Z. Liu, Q. Meng, R. Liu, Sun P. And Y. Chen, 2012, Quantitative evaluation of Oil Shale Based on Well Log and 3D Seismic Technique in the Songliao Basin, Northeast China: Oil Shale, v. 29, no. 2, p. 128-150.

Meissner F. F., 1978, Petroleum Geology of the Bakken Formation Williston Basin, North Dakota and Montana, the economic geology of Williston basin: Montana geological society, 1978 Williston Basin symposium, P. 207-227.

Olisa B. A. and O. Oke (2014), Well Log Correlation of Three Vertical Wells in the Niger Delta, IMPACT: International Journal of Research in Applied, Natural and Social Sciences (IMPACT: IJRANSS) ISSN(E): 2321-8851.

Olisa B. A. and C. Okafor (2014), Fault analysis using well logs in the Niger Delta, Nigeria

International Journal of Applied and Natural Sciences (IJANS)

ISSN(P): 2319-4014; ISSN(E): 2319-4022

Olisa B. A., B. D. Ako and J. S. Ojo (2018), Estimation of source rock organic richness from gamma ray (GR) log: Eocene section,

www.scirj.org

(C) 2021, Scientific Research Journal

http://dx.doi.org/10.31364/SCIRJ/v9.i10.2021.P1021887

This publication is licensed under Creative Commons Attribution CC BY. 
parts of the western Niger Delta, Nigeria, IOSR Journal of Applied Geology and Geophysics (IOSR-JAGG), e-ISSN: 2321-0990 [DOI: 10.9790/0990-0602014654]

Passey Q. R., S. Creaney, J. B. Kulla, F. J. Moretti and J. D. Stroud, 1990, A Practical Model for Organic-Richness from Porosity and Resistivity Logs: AAPG Bulletin, v. 74, no. 12, p. 1777-1794.

Rull V., 2002, High-impact palynology in petroleum geology: Application from Venezuela (northern South America): AAPG Bulletin, v. 86, No. 2, p. 279-300.

Short, K. C., and A. J. Stauble, (1967), Outline of geology of Niger Delta, Bull. Am. Assoc. Petrol. Geol, V. 51, P. 761-779.

Meyer B. L., and M. Y. Nederlof, (1984), Identification of Source Rock on Wireline Logs by Density/Resistivity and Sonic Transit time/Resistivity Crossplots: AAPG Bulletin v. 68, p. 121-129. 